\title{
GABA Binding and Bicuculline in Spinal Cord and Cortical Membranes from Adult Rat and from Mouse Neurons in Cell Culture
}

\author{
ROBERT C. FRERE, ROBERT L. MACDONALD and ANNE B. YOUNG
}

Netrosciences Program, and (R.L.M. and A.B.Y.) Department of Neurology, University of Michigan, Ann Arbor, MI 48109 (U.S.A.)

(Accepted December 24th, 1981)

Key words: GABA receptors - muscimol -- bicuculline - cultured neurons

Sodium-independent $\left[{ }^{3} \mathrm{H}\right] \mathrm{GABA}$ and $\left[{ }^{3} \mathrm{H}\right]$ muscimol binding was determined in adult rat cerebral cortical and spinal cord membranes and in membranes from fetal mouse cortical and spinal cord neurons in primary dissociated cell culture. In adult rat cerebral cortical membranes, $\left[{ }^{3} \mathrm{H}\right] \mathrm{GABA}$ bound to two sites $\left(K_{d}=8 \mathrm{nM}, \mathrm{B}_{\mathrm{max}}=0.62 \mathrm{pmol} / \mathrm{mg}\right.$ protein $; K_{d}=390 \mathrm{nM}, \mathrm{B}_{\mathrm{max}}=-$ $3.9 \mathrm{pmol} / \mathrm{mg}$ protein) whereas the GABA agonist, $\left[{ }^{3} \mathrm{H}\right]$ muscimol, bound only to a high affinity site $\left(K_{d}=5.6 \mathrm{nM}, \mathrm{B}_{\mathrm{max}}=1.9\right.$ $\mathrm{pmol} / \mathrm{mg}$ protein). In adult rat spinal cord, only a low affinity site was seen with [ $\left.{ }^{3} \mathrm{H}\right] \mathrm{GABA}\left(K_{d}=340 \mathrm{nM}, \mathbf{B}_{\mathrm{max}}=9.8 \mathrm{pmol} / \mathrm{mg}\right.$ protein) and only a high affinity site was seen with $\left[{ }^{3} \mathrm{H}\right]$ muscimol $\left(K_{d}=5.6 \mathrm{nM}, \mathrm{B}_{\max }=0.25 \mathrm{pmol} / \mathrm{mg}\right.$ protein $)$. The inability to measure a high affinity $\left[{ }^{3} \mathrm{H}\right] \mathrm{GABA}$ binding site in spinal cord probably reflects the high ratio of low to high affinity sites in spinal cord $(39: 1)$. In membranes from mouse neurons in cell culture, $\left[{ }^{3} \mathrm{H}\right] \mathrm{GABA}$ bound to two sites on cortical neurons $\left(K_{d}=-9\right.$ $\mathrm{nM}, \mathrm{B}_{\mathrm{max}}=0.24 \mathrm{pmol} / \mathrm{mg}$ protein $; K_{d}=510 \mathrm{nM}, \mathrm{B}_{\mathrm{max}}=1.3 \mathrm{pmol} / \mathrm{mg}$ protein $)$ and spinal cord neurons $\left(K_{d}=13 \mathrm{nM}, \mathbf{B}_{\mathrm{max}}=\right.$ $0.12 \mathrm{pmol} / \mathrm{mg}$ protein $; K_{d}=640 \mathrm{nM}, \mathrm{B}_{\mathrm{max}}=3.2 \mathrm{pmol} / \mathrm{mg}$ protein). Again, the ratio of low to high affinity sites in cultured mouse spinal cord neurons was high $(27: 1)$.

The effects of the potent GABA antagonist, $(+)$ bicuculline, on both low and high affinity $\left[{ }^{3} \mathrm{H}\right] \mathrm{GABA}$ binding was determined. Bicuculline appeared to inhibit binding to both sites competitively but the $K_{i}$ for inhibiting the high affinity site was $5 \mu \mathrm{M}$ and for inhibiting the low affinity site was $115 \mu \mathrm{M}$. Bicuculline inhibited $\left[{ }^{3} \mathrm{H}\right]$ muscimol binding in both brain and spinal cord competitively with $K_{i} \mathrm{~S}$ of $4 \mu \mathrm{M}$ and $10 \mu \mathrm{M}$ respectively. Bicuculline inhibition of [ $\left.{ }^{3} \mathrm{H}\right]$ muscimol binding in cultured neuronal membranes was similar to that in adult rat membranes.

The binding of the potent GABA agonist, muscimol, only to the high affinity site in both adult rat and cultured mouse neuronal membranes suggests that the high affinity site is the physiologically relevant postsynaptic GABA receptor. The fact that bicuculline inhibits the high affinity site (but not the low affinity site) in concentrations similar to those needed to block GABA-responses in physiological experiments ${ }^{28}$ supports this hypothesis.

\section{INTRODUCTION}

Binding studies have been developed in the past decade which have made it possible to measure synaptic GABA receptors biochemically $15,16,31,55$, ${ }^{56}$. [ $\left.{ }^{3} \mathrm{H}\right] \mathrm{GABA}$ binding shows a pharmacology and subcellular distribution similar to that expected for the postsynaptic GABA receptors. Binding is displaced by numerous GABA analogs and agonists. However, only certain antagonists, exemplified by the convulsant alkaloid bicuculline, appear to act directly to displace bound GABA ${ }^{15,56}$. Other GABA antagonists such as picrotoxin, penicillin and pentylenetetrazole have been found to have no effect on GABA binding ${ }^{33}$. $\left[{ }^{3} \mathrm{H}\right]$ bicuculline binding has been measured directly and binding was displaced by $\mathrm{GABA}^{7,27} \cdot\left[{ }^{3} \mathrm{H}\right]$ dihydropicrotoxinin binding has also been demonstrated and penicillin and pentylenetetrazole are capable of displacing the bound ligand but bicuculline and GABA are not ${ }^{32,48}$. These findings suggest that the GABA receptor complex may be composed of a number of subunits or independent sites which interact in the intact living cell but which can be partially dissociated and/or desensitized biochemically upon membrane isolation.

Early studies of $\left[{ }^{3} \mathrm{H}\right] \mathrm{GABA}$ binding to neuronal membranes demonstrated only one population of binding sites $15,29,56$; however, treatment of membranes with Triton X-100 $(0.05 \% \mathrm{v} / \mathrm{v})$ and/or re- 
peated freeze-thaw of the membranes followed by extensive washing yielded, in addition, a second, higher affinity GABA binding site ${ }^{16,55}$. It has been proposed that tritonization removes an endogenous inhibitor $18,20,50$ which may normally lower the affinity of the GABA receptor. The removal of this inhibitor by extensive washing, mild detergent treatment or phospholipase $\mathrm{C}$ increases the binding affinity for GABA nearly 100 -fold ${ }^{16,23}$. Additional evidence suggests that the benzodiazepines may prevent the binding of this inhibitor thus enhancing the affinity of the receptor for GABA ${ }^{20}$.

The high affinity GABA binding site may be involved in the development of supersensitivity. After denervation of substantia nigra by hemitransections, GABA receptors were found to become supersensitive by behavioral studies ${ }^{51}$ and, furthermore, the number of GABA receptors increased ${ }^{19}$, 52 . However, only the number of high affinity binding sites increased after the nigral deafferentation, with no change observed in the low affinity sites ${ }^{18,50}$. The high affinity site can be selectively assayed using Triton-treated membranes and $\left[{ }^{3} \mathrm{H}\right] \mathrm{muscimol}$ (a potent GABA agonist) $)^{3,44}$.

The above characteristics of the high affinity binding site suggest its association with GABAmediated postsynaptic inhibition. Nevertheless, the actual functions of the high and low affinity sites and which site mediates the physiological postsynaptic response remain uncertain. It is difficult to draw conclusions from the current literature because one must compare biochemical data from one preparation with physiological data from another. To make such comparisons, we have investigated GABA binding and physiology using mouse neurons in primary dissociated cell culture. Properties of GABAergic synaptic transmission have been investigated using chick and mouse neurons in cell culture ${ }^{10,11,17,45,49}$. The physiological actions of GABA and bicuculline on neurons in cell culture have also been studied $2,12,25,36$.

We have studied the properties of GABA receptors in membranes from adult rat spinal cord and cortical neurons and from mouse spinal cord and cortical neurons in primary dissociated cell culture. We have examined the effects of the potent convulsant bicuculline on GABA binding in order to compare biochemical and physiological effects. Bi- cuculline has been said to be a competitive inhibitor of GABA responses by some ${ }^{9,13}$ and noncompetitive by others ${ }^{41,42,47}$ but little detailed biochemical work has been performed on its effects on GABA binding in mammalian preparations. In conjunction with the following paper ${ }^{28}$, we have studied the mechanism of action of this drug and suggest which GABA binding site may have relevance to mediation of postsynaptic inhibition.

\section{MATERIALS AND METHODS}

\section{Primary dissociated cell culture}

Primary dissociated fetal mouse neuronal cell cultures were prepared as described previously 37 and used for binding studies. Spinal cords were dissected from 12-14-day murine fetuses and cortices were removed from 14-16-day fetuses. Dissected tissue was mechanically chopped and dissociated by trituration with a Pasteur pipette then trypsinized and grown in Eagles Minimum Essential Medium supplemented with heat inactivated horse serum $(10 \%$ $\mathrm{v} / \mathrm{v})$, fetal calf serum $(10 \% \mathrm{v} / \mathrm{v})$, glucose $(6 \mathrm{~g} / \mathrm{l})$, and sodium bicarbonate $(3.7 \mathrm{~g} / 1)$.

Spinal cord cells were plated at a density of 1/4-1/2 spinal cord per plate and cortical cells at 1/3 hemisphere per plate. Cells were grown on collagencoated culture dishes in a humidified $35{ }^{\circ} \mathrm{C}, 10 \%$ $\mathrm{CO}_{2} / 90 \%$ air incubator. Cultures were maintained for $4-8$ weeks and the medium changed semiweekly.

\section{Tissue preparation}

Rats were sacrificed by decapitation and the brains and spinal cords rapidly removed and frozen at $-20^{\circ} \mathrm{C}$ for $1-30$ days. Frozen rat cerebral cortex and spinal cord were homogenized in 50 vols: icecold $50 \mathrm{mM}$ Tris-citrate buffer, pH 7.1 at $4^{\circ} \mathrm{C}$ with a polytron homogenizer (setting 7 , for $30 \mathrm{~s}$ ). Triton $\mathrm{X}-100$ was added to make the homogenate $0.05 \%$ $\mathrm{v} / \mathrm{v}$ and the samples incubated for $30 \mathrm{~min}$ at $37^{\circ} \mathrm{C}$ and then centrifuged at $48,000 \mathrm{~g}$ for $10 \mathrm{~min}$. The pellet was then resuspended in fresh buffer and resedimented at $48,000 \mathrm{~g}$ for $10 \mathrm{~min}$. This washing procedure was repeated 3 times. For some experiments, crude synaptic membranes were prepared initially from fresh brain and spinal cord and tritonized as previously described ${ }^{16}$.

For tissue culture, spinal cord and cortical cul- 
tures were homogenized in 200 vols. ice-cold $50 \mathrm{mM}$ Tris-citrate buffer $\mathrm{pH} 7.1$ at $4{ }^{\circ} \mathrm{C}$ and Triton X-100 added to achieve a final concentration of $0.025 \%$ $\mathrm{v} / \mathrm{v}$. This homogenate was incubated at $37^{\circ} \mathrm{C}$ for 30 min and centrifuged at $48,000 \mathrm{~g}$ for $20 \mathrm{~min}$. The pellet was resuspended in fresh cold Tris-citrate buffer and washed twice.

\section{Binding studies}

The final washed pellets were resuspended in icecold $50 \mathrm{mM}$ Tris-citrate buffer $\mathrm{pH} 7.1$ and aliquots of the tissue suspension ( $0.1-0.3 \mathrm{mg}$ protein) were incubated in triplicate at $4{ }^{\circ} \mathrm{C}$ for $20 \mathrm{~min}$ in $2 \mathrm{ml}$ containing various concentrations of $\left[{ }^{3} \mathrm{H}\right]$ muscimol or $\left[{ }^{3} \mathrm{H}\right] \mathrm{GABA}$ and in the presence or absence of 0.1 $\mathrm{mM}$ GABA or $(+)$ bicuculline. For competition studies, the final incubation medium was $2-4 \mathrm{nM}$ $\left[{ }^{3} \mathrm{H}\right]$ muscimol or $\left[{ }^{3} \mathrm{H}\right] \mathrm{GABA}$. For saturation studies, the concentrations of $\left[{ }^{3} \mathrm{H}\right]$ muscimol varied from 3 to $100 \mathrm{nM}$ and those of $\left[{ }^{3} \mathrm{H}\right] \mathrm{GABA}$ from 5 to $800 \mathrm{nM}$. The assays were terminated by filtration under vacuum through Whatman $\mathrm{GF} / \mathrm{B}$ filters followed by three $5 \mathrm{ml}$ washings (each less than $3 \mathrm{~s}$ ) with ice-cold $25 \mathrm{mM}$ Tris-citrate buffer $\mathrm{pH} 7.1$ at 4 ${ }^{0} \mathrm{C}^{54}$. The filters were placed in $6 \mathrm{ml} \mathrm{ACS}$ (Amersham) and the amount of bound radioactivity determined by liquid scintillation spectrometry (Beckman LS- $8100,38 \%$ efficiency). 'Nonspecific' binding was estimated as the amount of radioactivity bound in the presence of $0.1 \mathrm{mM} \mathrm{GABA}$ or $(+)$ bicuculline. 'Specific' binding was obtained by subtracting nonspecific binding from total binding. Protein was determined by the method of Lowry et al. ${ }^{24}$.

\section{Materials}

Eagles Minimum Essential Medium, horse serum and calf serum were purchased from Gibco. $\left[{ }^{3} \mathrm{H}\right]-$ muscimol $(19 \mathrm{Ci} / \mathrm{mmol})$ and $\left[{ }^{3} \mathrm{H}\right] \mathrm{GABA} \quad(58$ $\mathrm{Ci} / \mathrm{mmol}$ ) were obtained from Amersham Corporation. $(+)$ Bicuculline, imidazoleacetic acid, 2,4-diaminobutyric acid, $\beta$-alanine, $\beta$-guandinoproprionic acid, $\gamma$-amino- $\beta$-hydroxybutyric acid, glycine and L-glutamic acid were all purchased from Sigma Chemicals. Muscimol was purchased from Research Organics.

\section{RESULTS}

\section{$\left[{ }^{3} H\right] G A B A$ binding in rat membranes}

$\left[{ }^{3} \mathrm{H}\right] \mathrm{GABA}$ binding in membranes from rat cere-
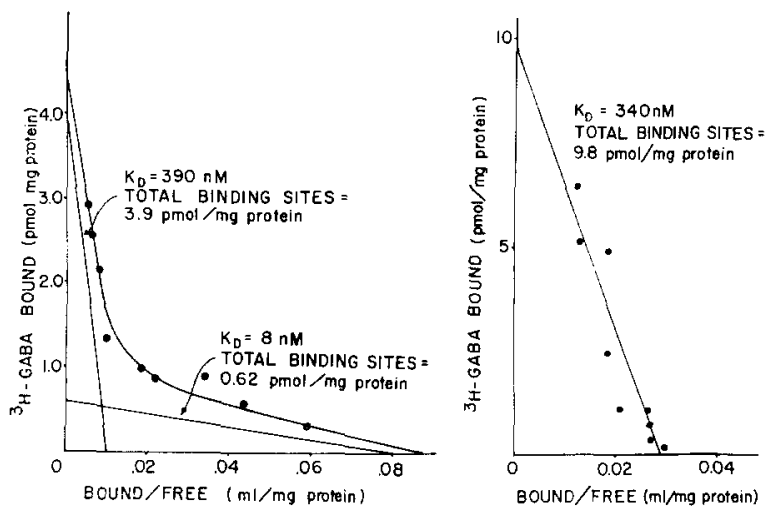

Fig. 1. Rosenthal analysis of specific $\left[{ }^{3} \mathrm{H}\right] \mathrm{GABA}$ binding in rat brain (left) and spinal cord (right). Membrane suspensions $(0.2-0.4 \mathrm{mg}$ protein $/ \mathrm{ml})$ were prepared as described in the text and incubated in triplicate with increasing concentrations of $\left[{ }^{3} \mathrm{H}\right] \mathrm{GABA}(5-800 \mathrm{nM})$. Specific binding was obtained by subtraction of the binding in the presence of $0.1 \mathrm{mM} \mathrm{GABA}$ from the total binding. Each point represents the mean of triplicate determinations. The experiment has been replicated 4 times.

bral cortex was saturable and Scatchard analysis ${ }^{38}$ of the data was most consistent with two sites (Fig. 1; Table I). When the two sites were separated by Rosenthal analysis ${ }^{38}$, the high affinity site had a $K_{d}$ of $8 \mathrm{nM}$ and $\mathrm{B}_{\max }$ of $0.62 \mathrm{pmol} / \mathrm{mg}$ protein; the low affinity site had a $K_{d}$ of $390 \mathrm{nM}$ and a $\mathrm{B}_{\max }$ of 0.62 $\mathrm{pmol} / \mathrm{mg}$ protein; the low affinity site had a $K_{d}$ of $390 \mathrm{nM}$ and $\mathrm{a} \mathrm{B}_{\max }$ of $3.9 \mathrm{pmol} / \mathrm{mg}$ protein. Further tritonization and/or washing after freeze-thaw of the membranes did not significantly alter the binding curve. Likewise, when binding studies were performed on a crude synaptic membrane fraction by a centrifugation assay ${ }^{15,56}$ similar saturation curves were obtained.

In spinal cord membranes, only a low affinity site for $\left[{ }^{3} \mathrm{H}\right] \mathrm{GABA}$ binding was demonstrable with a $K_{d}$ of $340 \mathrm{nM}$ and $\mathrm{B}_{\max }$ of $9.8 \mathrm{pmol} / \mathrm{mg}$ protein (Fig. 1; Table I). Using crude synaptic membrane fractions and a centrifugation assay, a consistent second site was also not demonstrable. Varying amounts of tritonization from 0.025 to $0.10 \%$ did not unmask a high affinity site.

\section{$\left[{ }^{3} \mathrm{H}\right]$ muscimol binding in rat membranes}

$\left[{ }^{3} \mathrm{H}\right]$ muscimol binding in tritonized rat cerebral cortex revealed only one site with a $K_{d}$ of $5.6 \mathrm{nM}$ and $B_{\max }$ of $1.9 \mathrm{pmol} / \mathrm{mg}$ protein (Fig. 2). In spinal cord, $\left[{ }^{3} \mathrm{H}\right]$ muscimol binding also had only a high affinity binding site with a $K_{d}$ of $5.6 \mathrm{nM}$ and $\mathrm{B}_{\max }$ of 
TABLE I

Summary of binding constants obtained from cortical and spinal cord membrane preparations

n.d., not determined; n.f., not found.

\begin{tabular}{llll} 
High affinity site & \multicolumn{2}{l}{ Low affinity } \\
\hline$K_{a}$ & $B_{\mathrm{max}}$ & $K_{a}$ & $B_{\mathrm{max}}$ \\
$(n M)$ & (pmol/mg protein) & $(n M)$ & (pmol/mg protein)
\end{tabular}

$\left[{ }^{3} \mathrm{H}\right] \mathrm{GABA}$ binding

Rat cerebral cortex

Rat spinal cord

$8 \quad 0.62$

n.f. n.f.

Cultured mouse cortex

$9 \quad 0.24$

Cultured mouse spinal cord

$13 \quad 0.12$

$\begin{array}{ll}390 & 3.9 \\ 340 & 9.8 \\ 510 & 1.3 \\ 640 & 3.2\end{array}$

$\left[{ }^{3} \mathrm{H}\right]$ muscimol binding

Rat cerebral cortex

Rat spinal cord

$5.6 \quad 1.90$

Cultured mouse cortex

$5.6 \quad 0.25$

$6.3 \quad 0.50$

Cultured mouse spinal cord

n.d.

n.d.

$\begin{array}{ll}\text { n.f. } & \text { n.f. } \\ \text { n.f. } & \text { n.f. } \\ \text { n.f. } & \text { n.f. } \\ \text { n.d. } & \text { n.d. }\end{array}$
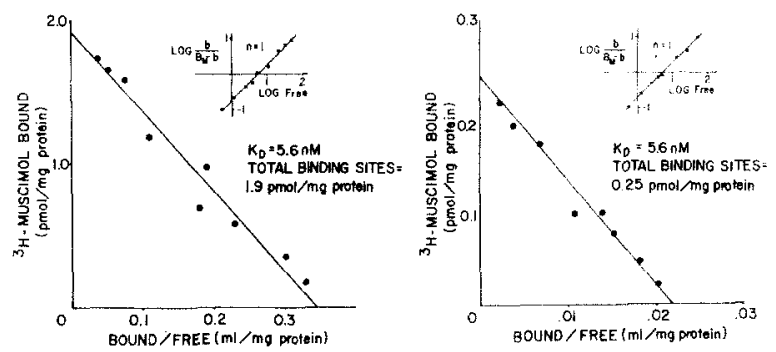

Fig. 2 Scatchard analysis of specific $\left[{ }^{3} \mathrm{H}\right]$ muscimol binding in rat brain (left) and spinal cord (right) membranes. Conditions were identical to those in Fig. 1 with the exception that various concentrations of $\left[{ }^{3} \mathrm{H}\right]$ muscimol $(3-100 \mathrm{nM})$ were used. Each point represents the mean of triplicate determinations. This experiment was typical of 4 separate experiments. The lines were derived by linear regression. Insets are the Hill plots of the same data.

$0.25 \mathrm{pmol} / \mathrm{mg}$ protein. Thus muscimol appeared to label specifically a high affinity binding site in washed tritonized membranes. Furthermore, the $\mathrm{B}_{\max }$ of the muscimol binding site in spinal cord was 0.25 $\mathrm{pmol} / \mathrm{mg}$ protein which was only $2.5 \%$ of the $\mathrm{B}_{\max }$ of the low affinity $\left[{ }^{3} \mathrm{H}\right] \mathrm{GABA}$ binding site. Hill plots of the binding curves in brain and spinal cord were linear with unity slope and thus the Hill coefficients were 1.0 (Fig. 2, insets).

\section{$\left[{ }^{3} \mathrm{H}\right] \mathrm{GABA}$ binding and $\left[{ }^{3} \mathrm{H}\right]$ muscimol binding in cultured mouse cortical and spinal cord neurons}

$\left[{ }^{3} \mathrm{H}\right] \mathrm{GABA}$ binding to tritonized membranes of mouse cortical neurons in dissociated cell culture was similar to that in rat cerebral cortex membranes with a low affinity site $\left(K_{d} 510 \mathrm{nM}\right.$ and $B_{\max } 1.3$ $\mathrm{pmol} / \mathrm{mg}$ protein) and a high affinity site $\left(K_{d} 9 \mathrm{nM}\right.$ and $B_{\max } 0.24 \mathrm{pmol} / \mathrm{mg}$ protein) (Fig. 3). As in rat membranes, $\left[{ }^{3} \mathrm{H}\right]$ muscimol binding revealed only the high affinity site $\left(K_{d} 6.3 \mathrm{nM}\right.$ and $\mathrm{B}_{\max } 0.5$ pmol/mg protein) (inset, Fig. 3) (Table I).

Unlike rat spinal cord membranes, however, membranes of mouse spinal cord neurons in cell culture displayed both a high affinity site $\left(K_{d} 13 \mathrm{nM}\right.$ and $B_{\max } 0.12 \mathrm{pmol} / \mathrm{mg}$ protein) and a low affinity site ( $K_{d} 640 \mathrm{nM}$ and $\mathrm{B}_{\max } 3.2 \mathrm{pmol} / \mathrm{mg}$ protein) with $\left[{ }^{3} \mathrm{H}\right] \mathrm{GABA}$ similar to those seen in membranes from cortical neurons (Fig. 3). The amount of membrane obtained from culture plates was small and it was more difficult to obtain accurate saturation studies using membranes from neurons in cel!
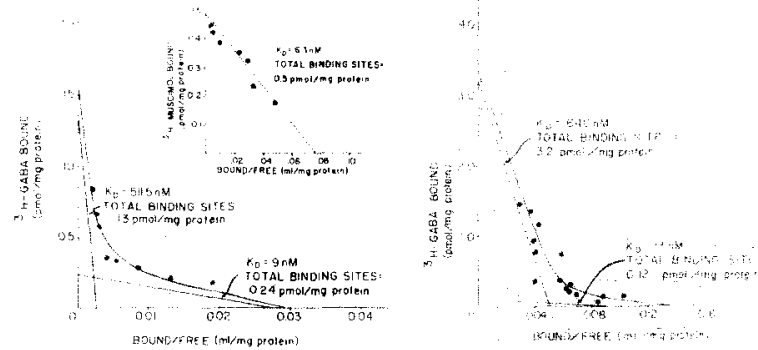

Fig. 3. Rosenthal analysis of specific $\left[{ }^{3} \mathrm{H}\right] \mathrm{GABA}$ binding to membranes from cortical (left) and spinal cord (right) cell cultures. Membrane suspensions were prepared as described in text and assayed as in Fig. 1. Inset on the left is the Scatchard analysis of specific $\left[{ }^{3} \mathrm{H}\right] \mathrm{muscimol}$ binding to cortical culture under identical conditions. Each point is the mean of triplicate determinations. Lines were derived by linear regression. Each experiment was repeated at least 3 times. 
culture than using adult rat membranes. Our studies nevertheless have always indicated curvilinear Scatchard analyses using membranes from spinal cord in cell culture. At present we have not performed saturation studies with $\left[{ }^{3} \mathrm{H}\right]$ muscimol using spinal cord neurons in cell culture.

\section{Competition studies of $\left[{ }^{3} \mathrm{H}\right]$ muscimol binding in adult} rat and cultured mouse neuronal tissues

Competition studies of $\left[{ }^{3} \mathrm{H}\right]$ muscimol binding in spinal cord and cerebral cortex membranes from adult rat and in membranes from cultured mouse cortical neurons were similar (Table II). The $\mathrm{IC}_{50}$ s of a variety of GABA agonists were similar to those previously reported $15,30,31,56$ for GABA receptors with muscimol being most potent with an $\mathrm{IC}_{50}$ of 6 $\mathrm{nM}$, GABA next most potent followed by imidazoleacetic acid, $\gamma$-amino- $\beta$-hydroxybutyric acid and $\beta$ guanidinoproprionic acid. $\beta$-Alanine which wasquite weak in displacing $\left[{ }^{3} \mathrm{H}\right]$ muscimol binding. Glycine and glutamic acid, two other putative amino acid neurotransmitters, were virtually inactive in competing for binding as was the uptake inhibitor, 2,4diaminobutyric acid. $(\div)$ Bicuculline potently competed for $\left[{ }^{3} \mathrm{H}\right]$ muscimol binding but picrotoxin was inactive as previously reported ${ }^{3}$.
Bicuculline displacement of $\left[{ }^{3} \mathrm{H}\right] \mathrm{GABA}$ and $\left[{ }^{3} \mathrm{H}\right]$ muscimol in rat cerebral cortex and spinal cord membranes

$(+)$ Bicuculline displaced $\left[{ }^{3} \mathrm{H}\right] \mathrm{GABA}$ binding to tritonized rat cerebral cortex and spinal cord membranes (Fig. 4). In brain, (+)bicuculline had an $\mathrm{IC}_{50}$ of $5 \mu \mathrm{M}$ whereas in spinal cord, the $\mathrm{IC}_{50}$ was $40 \mu \mathrm{M}$. This appeared as a major discrepancy between brain

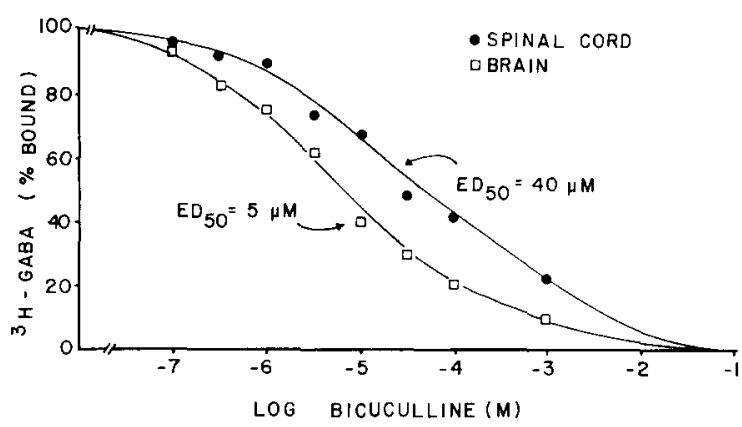

Fig. 4. Semilog plot of displacement of specific $\left[{ }^{3} \mathrm{H}\right] \mathrm{GABA}$ binding by $(+$ )bicuculline in brain and spinal cord membranes. Membrane suspensions were prepared as described in text and incubated in triplicate with [ $\left.{ }^{3} \mathrm{H}\right] \mathrm{GABA}(2-4 \mathrm{nM})$ and various concentrations of $(+)$ bicuculline. Specific binding was obtained by subtracting the amount bound in the presence of $0.1 \mathrm{mM} \mathrm{GABA}$ from the total binding. Each point is the mean of triplicate determinations and the experiment has been repeated 5 times.

\section{TABLE II}

Competition studies for $\left.{ }^{[3} \mathrm{H}\right]$ muscimol binding in adult rat cerebral cortical and spinal cord membranes and membranes from fetat mouse cortical heurons grown in PDC

In these experiments $\left[{ }^{3} \mathrm{H}\right]$ muscimol concentration was $2-4 \mathrm{nM}$ and the $K_{d}$ for $\left[{ }^{3} \mathrm{H}\right]$ muscimol was $4-8 \mathrm{nM}$. Thus the $K_{i}$ values would be $2 / 3 I_{50}$ in each case. $\left(K_{i}=\mathrm{IC}_{50} /\left(1+[\mathrm{L}] / K_{d}\right)\right)$. The data was obtained from competition studies. Each value is the mean of the $\mathrm{IC}_{50 \mathrm{~s}}$ from 3 separate experiments that varied less than $15 \%$.

\begin{tabular}{|c|c|c|c|}
\hline \multirow[t]{3}{*}{ Compound } & \multicolumn{3}{|c|}{$I C_{50}(\mu M)$ for inthibition of $\left[{ }^{3} \mathrm{H}\right]$ muscimol binding } \\
\hline & \multicolumn{2}{|l|}{ Adult rat } & \multirow{2}{*}{$\frac{\text { Cultured neurons }}{\text { Cortical neurons }}$} \\
\hline & Spinal cord & Brain & \\
\hline Muscimol & 0.006 & 0.006 & 0.006 \\
\hline GABA & 0.030 & 0.044 & 0.025 \\
\hline Imidazoleacetic acid & 0.9 & 0.6 & 0.6 \\
\hline$\gamma$-Amino- $\beta$-hydroxybutyric acid & 1.1 & 0.7 & 0.4 \\
\hline$\beta$-Guanidinoproprionic acid & 0.6 & 0.7 & 0.4 \\
\hline$\beta$-Alanine & 10 & 10 & 45 \\
\hline Glycine & $>1000$ & 1000 & $\therefore 1000$ \\
\hline 2,4-Diaminobutyric acid & $>1000$ & $>1000$ & 1000 \\
\hline L-Glutamic acid & $>1000$ & 1000 & 1000 \\
\hline$(+)$ Bicuculline & 16 & 5 & 5 \\
\hline Picrotoxin & $>1000$ & $\because 1000$ & $>1000$ \\
\hline
\end{tabular}




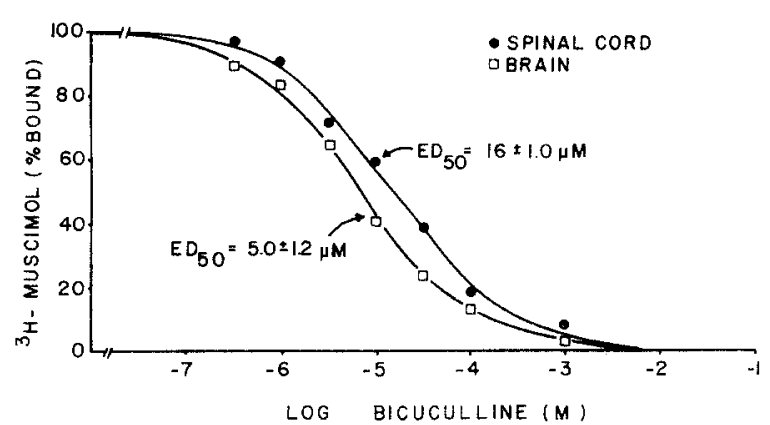

Fig. 5. Semilog plot of displacement of specific $\left[{ }^{3} \mathrm{H}\right]$ muscimol binding by $(+)$ bicuculline in brain and spinal cord membranes. Conditions were identical to those in Fig. 4 except that $\left[{ }^{3} \mathrm{H}\right]$ muscimol $(2-4 \mathrm{nM})$ was used as the ligand. Each point represents the mean of triplicate determinations. The $\mathrm{ED}_{50} \mathrm{~S}$ are the mean $\pm \mathrm{S}$.E.M. of the $\mathrm{ED}_{50}$ s from 3 separate experiments.

and spinal cord and was present whether assays were performed on washed and tritonized whole cord membranes or on crude synaptic membrane fractions. In contrast, when (+)bicuculline displacement of $\left[{ }^{3} \mathrm{H}\right]$ muscimol binding was investigated, the IC $_{50}$ in spinal cord $(16 \mu \mathrm{M})$ was much closer to that in brain ( $5 \mu \mathrm{M})$ (Fig. 5).

Bicuculline is not a stable compound at neutral $\mathrm{pH}^{29}$, therefore solutions were made up fresh daily in $0.02 \mathrm{~N} \mathrm{HCl}$ and dilutions added to the reaction mixture just prior to the assay. A series of bicuculline displacement curves of $\left[{ }^{3} \mathrm{H}\right]$ muscimol binding were performed at various times after adding $(+)$ bicuculline to the $50 \mathrm{mM}$ Tris-citrate buffer $\mathrm{pH} 7.1$. No change in the $\mathrm{IC}_{50}$ for (+)bicuculline displacement of $\left[{ }^{3} \mathrm{H}\right]$ muscimol was detectable until between $\mathrm{I}$ and $2 \mathrm{~h}$ after the addition of the $(+)$ bicuculline to neutral medium. By $4 \mathrm{~h}$, there was an approximately $20 \%$ increase in the $\mathrm{IC}_{50}$. Finally, spinal cord displacement curves were always run prior to the cerebral cortex curves on any given day to make certain that the increased $\mathrm{IC}_{50}$ in spinal cord was not secondary to a degradative phenomenon.

To investigate the mechanism of bicuculline displacement of $\left[{ }^{3} \mathrm{H}\right] \mathrm{GABA}$ binding in brain and spinal cord, saturation curves were performed on brain and spinal cord membranes in the presence of various concentrations of bicuculline. In brain, where two GABA binding sites were demonstrated, $(+)$ bicuculline at $10 \mu \mathrm{M}$ affected the high affinity site but not the low affinity site (Fig. 6). Furthermore, by separating the high and low affinity sites by
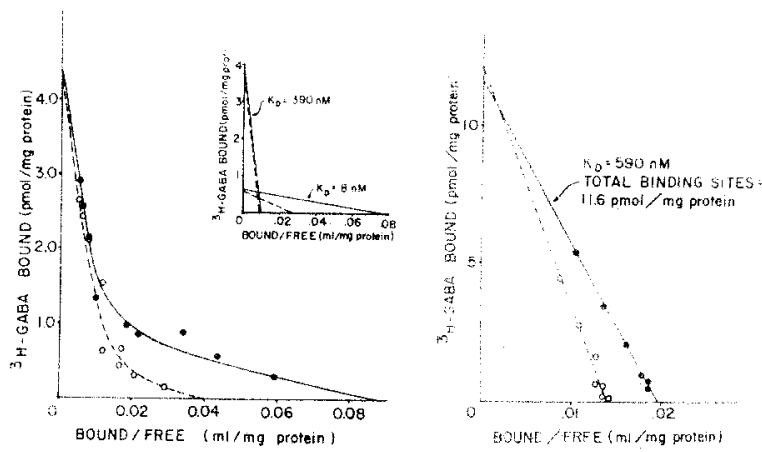

Fig. 6. Scatchard analyses of specific $\left[{ }^{3} \mathrm{H}\right] \mathrm{GABA}$ binding to brain (left) and spinal cord (right) membranes alone $(O)$ or in the presence $(O)$ of $(+)$ bicuculline. In brain, the concentration of bicuculline was $10 \mu \mathrm{M}$ and in spinal cord, it was 50 $\mu \mathrm{M}$. Saturation curves were performed as described in Fig. 1. The inset in the left-hand figure represents the Rosenthal analyses of the saturation curves from brain. The experiment has been replicated 3 times.

Rosenthal analysis ${ }^{38}$, bicuculline appeared to inhibit high affinity $\left[{ }^{3} \mathrm{H}\right] \mathrm{GABA}$ binding competitively (Fig. 6 , inset). In spinal cord where only a low affinity site was seen with $\left[{ }^{3} \mathrm{H}\right] \mathrm{GABA}$, bicuculline at $50 \mu \mathrm{M}$ also appeared to be competitive (Fig. 6). At the low affinity sites, the $K_{i}$ for $(+)$ bicuculline calculated fre $m$ the dose ratio method ${ }^{8}$ or from the slope of the Scatchard plot ${ }^{22}$ was $115 \mu \mathrm{M}$. In both spinal cord and rat brain membranes, $(+)$-bicuculline appeared to inhibit $\left[{ }^{3} \mathrm{H}\right]$ muscimol binding competitively (Fig. 7) with $K_{i}$ s of $4 \mu \mathrm{M}$ and $10 \mu \mathrm{M}$ for brain and spinal cord, respectively, calculated from slopes of Scatchard plots. These $K_{i}$ s obtained from saturation studies agree well with $K_{i}$ s obtained from competition studies.
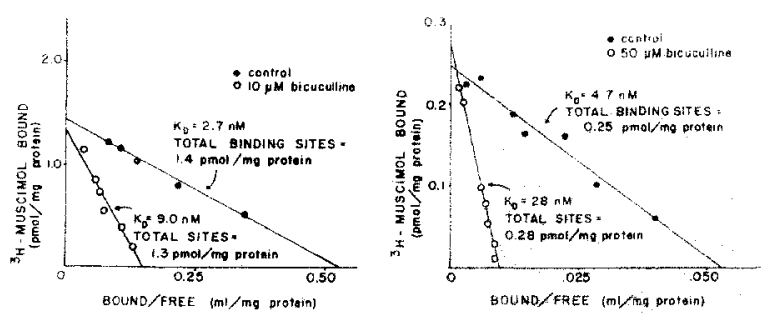

Fig. 7. Scatchard analyses of specific $\left[{ }^{3} \mathrm{H}\right]$ muscimol binding to brain (left) and spinal cord (right) membranes alone (O) or in the presence $(\bigcirc)$ of $(+)$ bicuculline (concentrations indicated in figure). Saturation curves were performed as in Fig. 2. Lines were derived by linear regression. The experiment has been replicated 4 times. 


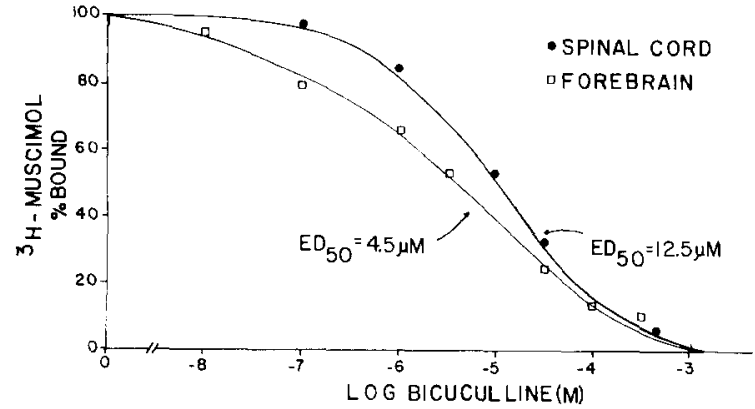

Fig. 8. Semilog plot of displacement of specific $\left[{ }^{3} \mathrm{H}\right]$ muscimol binding by $(+)$ bicuculline in membranes from cortical and spinal cord cultures. Membrane suspensions were prepared as described in text and assayed with the same conditions as those in Fig. 5. Each point is the mean of triplicate determinations and is typical of each of 3 separate experiments.

\section{$(+)$ Bicuculline displacement of $\left[{ }^{3} \mathrm{H}\right]$ muscimol bind-} ing to mouse spinal cord and cortical neurons in cell culture

$(+)$ Bicuculline displaced $\left[{ }^{3} \mathrm{H}\right]$ muscimol binding in membranes from cortical ( $\mathrm{IC}_{50} 4.5 \mu \mathrm{M}$ ) and spinal cord $\left(\mathrm{IC}_{50} 12.5 \mu \mathrm{M}\right)$ neurons in cell culture with potencies similar to those found in adult rat cerebral cortex and spinal cord membranes (Fig. 8). There appeared to be a slight tendency for bicuculline to be less potent in spinal cord than brain. Saturation curves in the presence of bicuculline have not been performed in culture secondary to the difficulty of these experiments.

\section{DISCUSSION}

GABA receptors are distributed throughout the central nervous system and much is known about their physiological, pharmacological and biochemical properties. In brain, biochemical studies of GABA receptors have revealed two sodium-independent binding sites for tritiated GABA in tritonized or frozen and extensively washed membranes $16,18,30,55$. The density and regional distribution of the two sites appear to vary independently throughout the $\mathrm{CNS}^{35}$. The function of the different binding sites is unknown. We have studied GABA receptors in adult rat and cultured mouse spinal cord neurons so that biochemical data could be compared with neurophysiological data obtained from the same preparation ${ }^{28}$.

As observed by others ${ }^{16,30}$, we found two binding sites for $\left[{ }^{3} \mathrm{H}\right] \mathrm{GABA}$ in tritonized membranes from cerebral cortex. However, in extensive studies, we have only been able to demonstrate one binding site for $\left[{ }^{3} \mathrm{H}\right] \mathrm{GABA}$ in spinal cord. This is a low affinity site. Tritiated muscimol on the other hand labeled a high affinity site in both brain and spinal cord. In brain, the ratio of low to high affinity $\left[{ }^{3} \mathrm{H}\right] \mathrm{GABA}$ binding sites was 6.3:1 and that of low affinity GABA binding sites to high affinity $\left[{ }^{3} \mathrm{H}\right]$ muscimol binding sites was $2: 1$. In contrast, in spinal cord the ratio of low affinity $\left[{ }^{3} \mathrm{H}\right] \mathrm{GABA}$ binding sites to high affinity $\left[{ }^{3} \mathrm{H}\right]$ muscimol binding sites was $40: 1$. In neurons in cell culture, similar relationships were seen. The ratio of low to high affinity $\left[{ }^{3} \mathrm{H}\right] \mathrm{GABA}$ binding sites in brain was 5.3:1 and in spinal cord $27: 1$. Thus with both adult and cultured murine spinal cord neurons, the low affinity $\left[{ }^{3} \mathrm{H}\right] \mathrm{GABA}$ binding site was present in concentrations 25-40 times that of the high affinity binding site. $\left[{ }^{3} \mathrm{H}\right]$ Muscimol labeled only a high affinity site in both brain and spinal cord tritonized membranes. Hill coefficients of unity were found for the dose-response curves for $\left[{ }^{3} \mathrm{H}\right]$ muscimol binding in brain and spinal cord membranes which suggests that there is one population of mutually independent high affinity binding sites.

One implication of the high ratio of low affinity $\left[{ }^{3} \mathrm{H}\right] \mathrm{GABA}$ binding sites to high affinity sites in spinal cord is that even at the low ligand concentrations $(2-5 \mathrm{nM})$ used in routine binding assays with $\left[{ }^{3} \mathrm{H}\right] \mathrm{GABA} 30-50 \%$ of the observed binding is to the low affinity site (assuming reversible ligandreceptor interactions where $K_{d}=\left[\mathrm{B}_{\max }\right][\mathrm{L}] / \mathrm{B}$ and B $=$ bound ligand, $B_{\max }=$ maximum number of binding sites, $\mathrm{L}=$ ligand concentration and $K_{d}=$ the dissociation constant ${ }^{8}$ ). In order to look reliably for changes in the high affinity site in spinal cord, it would be preferential to study $\left[{ }^{3} \mathrm{H}\right]$ muscimol binding. In brain, either ligand is adequate since only $5-15 \%$ of GABA binding is to the low affinity site at 2-5 nM.

In studying bicuculline displacement of $\left[{ }^{3} \mathrm{H}\right]-$ GABA in spinal cord, the effects of the low affinity site also became apparent. (-) Bicuculline had an apparent $\mathrm{IC}_{50}$ of $40 \mu \mathrm{M}$ in displacing [ $\left.{ }^{3} \mathrm{H}\right] \mathrm{GABA}$ (2 $\mathrm{nM})$ in spinal cord. In experiments in spinal cord using $100 \mathrm{nM}\left[{ }^{3} \mathrm{H}\right] \mathrm{GABA}$ when $90 \%$ of the binding is to the low affinity site, the $\mathrm{IC}_{50}$ for $(+$ )bicuculline displacement of $\left[{ }^{3} \mathrm{H}\right] \mathrm{GABA}$ binding was 100 
$\mu \mathrm{M}$ (data not shown). When $\left[{ }^{3} \mathrm{H}\right]$ muscinol was the ligand, (+)bicuculline has an $\mathrm{IC}_{50}$ of $16 \mu \mathrm{M}$, which is similar to but nevertheless slightly higher than the $\mathrm{IC}_{50}$ for (+)bicuculline displacement of $\left[{ }^{3} \mathrm{H}\right] \mathrm{GABA}$ or $\left[{ }^{3} \mathrm{H}\right]$ muscimol binding in brain membranes.

Saturation curves of $\left[{ }^{3} \mathrm{H}\right] \mathrm{GABA}$ binding in the presence and absence of $10 \mu \mathrm{M}(+)$ bicuculline in brain showed competitive inhibition of the high affinity binding site with no significant alteration of the low affinity site. In spinal cord, $10 \mu \mathrm{M}$ bicuculline had little effect on the $\left[{ }^{3} \mathrm{H}\right] \mathrm{GABA}$ binding. The $K_{i}$ for the high affinity site calculated from the Scatchard analyses (slope in presence of bicuculline equals $\left.\left(1+[\mathrm{I}] / K_{i}\right)\right)$ was $5 \mu \mathrm{M}$ for the high affinity site in brain. At $50 \mu \mathrm{M}$ however, bicuculline inhibited [ $\left.{ }^{3} \mathrm{H}\right]$ GABA binding competitively in spinal cord and the $K_{i}$ for $(+)$ bicuculline at the low affinity site was $115 \mu \mathrm{M}$ as calculated from saturation studies in the presence of $(+)$ bicuculline. Previous investigations ${ }^{5,14}$ have found little or no regional variation in the potency of bicuculline for inhibiting $\left[{ }^{3} \mathrm{H}\right] \mathrm{GABA}$ binding but most of these studies were focusing on the high affinity site.

The high $K_{i}$ for bicuculline inhibition of low affinity $\left[{ }^{3} \mathrm{H}\right] \mathrm{GABA}$ binding is less than the $\mathrm{IC}_{50}$ for bicuculline inhibition of high affinity GABA-transport (about $400 \mu \mathrm{M}$ ) 29,34 . The GABA transport system is very sensitive to triton and freezing, and is highly temperature- and sodium-dependent ${ }^{26}$. These binding studies were performed on frozen and tritonized membranes in the absence of sodium, and it is thus unlikely that this low affinity binding site is the same as the transport site. A further reason against the low affinity site representing binding to the uptake site is that the number of low affinity sites have been found not to change in the projection areas of GABAergic pathways after lesion of the GABAergic neurons ${ }^{19,52}$. For this same reason, it is unlikely that the low affinity site represents binding to presynaptic autoreceptors on GABAergic neurons. However, the low affinity site could represent presynaptic receptors on other non-GABAergic nerve terminals. These presynaptic receptors have been demonstrated experimentally and although there is some controversy in the literature, evidence exists that these sites are pharmacologically distinct from the postsynaptic GABA receptors ${ }^{1,4,39,46}$. Furthermore, these presynaptic sites have been found to be relatively bicuculline insensitive. The pharmacology of the low affinity site in spinal cord must be studied in detail before it can be related to any specific function. Reports of drug effects on mixed high and low affinity $\left[{ }^{3} \mathrm{H}\right]$ GABA binding have utilized ligand concentrations in which $75 \%$ of the binding was to the high affinity site ${ }^{30}$.

The effect of bicuculline on $\left[{ }^{3} \mathrm{H}\right]$ muscimol binding in both brain and spinal cord appeared competitive ( $K_{i} \mathrm{~S}$ of $4 \mu \mathrm{M}$ for brain and $10 \mu \mathrm{M}$ for spinal cord). Although bicuculline appears to be competitive with GABA in these binding studies, it should be noted that apparent competitive inhibition does not necessarily indicate binding of the inhibitor to the same site as that of the ligand ${ }^{6}$. In this respect, there are some inconsistent properties of the inhibition of GABA binding by bicuculline. Firstly, there is the lack of effect of tritonization and or freeze-thaw and extensive washing on the bicuculline $\mathrm{IC}_{50}$ for displacing GABA binding despite an almost 10-100fold increase in the affinity of GABA itself for its receptor after these procedures ${ }^{16}$. Furthermore, various anions enhance the potency of bicuculline for inhibiting GABA-binding, but the same anions have no substantial effects on GABA binding ${ }^{5,16}$. These properties suggest that the interaction of bicucultine with GABA receptors may be more complicated than indicated by these kinetic studies.

Our studies indicate that the binding properties of $\left[{ }^{3} \mathrm{H}\right]$ muscimol and $\left[{ }^{3} \mathrm{H}\right]$ GABA in spinal cord and cortical neurons in PDC culture are quite similar to those in adult rat nervous system. Two binding sites for $\left[{ }^{3} \mathrm{H}\right] \mathrm{GABA}$ are found in cortical and spinal cord neurons although the ratio of low to high affinity sites is very much higher in spinal cord neurons than in cortical neurons. As in rat nervous system, $(+)$ bicuculline inhibits $\left[{ }^{3} \mathrm{H}\right]$ muscimol binding in cultured forebrain neurons slightly more potently than in spinal cord neurons. Although we have not performed saturation studies in the presence of bicuculline in cultured neurons, the similarities of the receptors in the two systems and the neurophysiological data ${ }^{28}$ obtained from neurons in cell culture suggest that bicuculline also would display competitive inhibition in cultured neurons.

In other systems, the low affinity receptor site is thought to be the physiologically relevant: one (3,53. $^{3}$. In these studies, the potent GABA agonist, musci- 
mol, binds preferentially to high affinity GABA receptors and bicuculline inhibits high affinity binding at doses similar to those effective physiologically ${ }^{28}$. The high $K_{i}$ for bicuculline blockade of the low affinity site is inconsistent with current knowledge of the postsynaptic GABA receptor. Thus, our experiments suggest that the high affinity site represents the postsynaptic GABA receptor. The following paper gives further evidence for this conclusion by presenting the physiological properties of postsynaptic GABA responses and their inhibition by bicuculline using mammalian neurons primary dissociated cell culture ${ }^{28}$.

\section{REFERENCES}

1 Arbilla, S., Kamal, L. and Langer, S. Z., Presynaptic GABA autoreceptors on GABAergic nerve endings of the rat substantia nigra, Europ. J. Pharmacol., 57 (1979) 211-217.

2 Barker, J. L. and Ransom, B. R., Amino acid pharmacology of mammalian central neurones grown in tissue culture, J. Physiol. (Lond.), 280 (1978) 331-354.

3 Beaumont, K., Chilton, W. S., Yamamura, H. I. and Enna, S. J., Muscimol binding in rat brain: association with synaptic GABA receptors, Brain Research, 148 (1978) 153-162.

4 Bowery, N. G., Hill, D. R., Hudson, A. L., Doble, A., Middlemiss, D. N., Shaw, J. and Turnbull, M., (-) Baclofen decreases neurotransmitter release in the mammalian CNS by action at a novel GABA receptor, Nature (Lond.), 283 (1980) 92-94.

5 Browner, M., Ferkany, J. W. and Enna, S. J., Biochemical identification of pharmacologically and functionally distinct GABA receptors in rat brain, $J$. Neurosci., 1 (1981) 514-518.

6 Cleland, W. W., The kinetics of enzyme catalyzed reactions with two or more substrates or products. III. Prediction of initial velocity and inhibition patterns by inspection, Biochim. biophys. Acta, 67 (1963) 188-196.

7 Collins, J. F. and Cryer, G., A study of the GABA receptor using ${ }^{3} \mathrm{H}$-bicuculline methobromide. In $\mathrm{F}$. Fonnum (Ed.), Amino Acids As Chemical Transmitters, Raven Press, New York, 1978, pp. 499-506.

8 Cuatrecasas, P. and Hollenberg, M. D., Membrane receptors and hormone action, Advanc. Protein Chem., 30 (1976) $251-451$.

9 Curtis, D. R., Duggan, A. W., Felix, D. and Johnston, G. A. R., GABA, bicuculline and central inhibition, Nature New Biol., 226 (1970) 1222-1224.

10 DeFeudis, F. V., Ossola, L., Schmitt, G. and Mandel, P., High-affinity binding of $\left[{ }^{3} \mathrm{H}\right]$ muscimol to subcellular particles of a neurone-enriched culture of embryonic rat brain, Neurosci. Lett., 14 (1979) 195-199.

11 DeFeudis, F. V., Ossola, L., Schmitt, G., Wolff, P. and Mandel, P., Na ${ }^{+}-$-independent binding of $\left[{ }^{3} \mathrm{H}\right] \mathrm{GABA}$ and [ $\left.{ }^{3} \mathrm{H}\right]$ muscimol to subcellular particles of neural primary cultures and whole brain, J. Neurochem., 34 (1980) 216-218

\section{ACKNOWLEDGEMENTS}

The authors thank Francis Hospod for expert technical assistance and Aileen BeMent and Kathy Lundquist for secretarial help. These studies were supported by the United Cerebral Palsy Research and Educational Foundation, Inc. and USPHS Grants NS 15140 (A.B.Y.) and NS 15225 (R.L.M). A.B.Y. is the recipient of a NIH Teacher Investigator Development Award NS 00420. R.L.M. is the recipient of a NIH Research Career Development Award NS 00408.

12 Dichter, M. A., Physiological identification of GABA as the inhibitory transmitter for mammalian cortical neurons in cell culture, Brain Research, 190 (1980) 111-121.

13 Enna, S. J., Collins, J. F. and Snyder, S. H., Stereospecificity and structure-activity requirements of GABA receptor binding in rat brain, Brain Research, 124 (1977) 185-190.

14 Enna, S. J., Ferkany, J. W. and Krogsgaard-Larsen, P., Pharmacological characteristics of GABA receptors in different brain regions. In $\mathrm{P}$. Krogsgaard-Larsen, J. Scheel-Kruger and $\mathrm{H}$. Kofod (Eds.), GABA-Neurotransmitters, Academic Press, New York, 1978, pp. 191-200.

15 Enna, S. J. and Snyder, S. H., Properties of $\gamma$-aminobutyric acid (GABA) receptor binding in rat brain synaptic membrane fractions, Brain Research, 100 (1975) $81-97$.

16 Enna, S. J. and Snyder, S. H., Influences of ions, enzymes and detergents on $\gamma$-aminobutyric acid-receptor binding in synaptic membranes of rat brain, Molec. Pharmacol., 13 (1977) $442-453$.

17 Farb, D. H., Berg, D. K. and Fischbach, G. D., Uptake and release of $\left[{ }^{3} \mathrm{H}\right]-\gamma$-aminobutyric acid by embryonic spinal cord neurons in dissociated cell culture, J. Cell Biol., 80 (1979) 651-661.

18 Greenlee, D. V., Van Ness, P. C. and Olsen, R. W., Endogenous inhibitor of GABA binding in mammalian brain, Life Sci., 22 (1978) 1653-1662.

19 Guidotti, A., Gale, K., Suria, A. and Toffano, G., Biochemical evidence for two classes of GABA receptors in rat brain, Brain Research, 172 (1979) 566-571.

20 Guidotti, A., Toffano, G. and Costa, E., An endogenous protein modulates the affinity of GABA and benzodiazepine receptors in rat brain, Nature (Lond.), 275 (1978) $553-555$.

21 Johnston, G. A. R. and Kennedy, S. M., GABA receptors and phospholipids. In F. Fonnum (Ed.), Amino Acids as Chemical Transmitters, Plenum Press, New York, 1978 , pp. 507-516.

22 Lehninger, A. L., Biochemistry, 2nd Edn., Worth Publishhers, New York, 1975, pp. $197 \mathrm{ff}$.

23 Lloyd, K. G. and Davidson, L., $\left[{ }^{3} \mathrm{H}\right] \mathrm{GABA}$ binding in brains from Huntington's chorea patients: altered regulation by phospholipids, Science, 205 (1979) 1147-1149.

24 Lowry, O. H., Rosebrough, N. J., Farr, A. L. and 
Randall, R. J., Protein measurement with Folin phenol reagent, J. biol. Chem., 193 (1951) 265-275.

25 Macdonald, R. L. and Barker, J. L., Specific antagonism of GABA-mediated postsynaptic inhibition in cultured mammalian spinal cord neurons: a common mode of convulsant action, Neurology, 28 (1978) 325-330.

26 Martin, D. L., Carrier-mediated transport and removal of GABA from synaptic regions. In E. Roberts, T. N. Chase and D. B. Tower, (Eds.), GABA in Nervous System Function, Raven Press, New York, 1976, pp. 347-386.

27 Möhler, H. and Okada, T., GABA receptor binding with ${ }^{3} \mathrm{H}(+)$ bicuculline-methiodide in rat CNS, Nature (Lond.), 267 (1977) 65-67.

28 Nowak, L. M., Young, A. B. and Macdonald, R. L., GABA and bicuculline actions on mouse spinal cord and cortical neurons in cell culture, Brain Research, 244 (1982) 155-164.

29 Olsen, R. W., Ban, M. and Miller, T., Studies on the neuropharmacological activity of bicuculline and related compounds, Brain Research, 102 (1976) 283-299.

30 Olsen, R. W., Bergman, M. O., VanNess, P. C., Lummis, S. C., Watkins, A. E., Napias, C. and Greenlee, D. V., $\gamma$-Aminobutyric acid receptor binding in mammalian brain. Heterogeneity of binding sites, Molec. Pharmacol., 19 (1981) 217-227.

31 Olsen, R. W., Greenlee, D., VanNess, P. and Ticku, M. $K$., Studies on the gamma-aminobutyric acid receptor ionophore proteins in mammalian brain. In F. Fonnum (Ed.), Amino Acids As Chemical Transmitters, Plenum Press, New York, 1978, pp. 467-486.

32 Olsen, R. W. and Leeb-Lundberg, R., Convulsant and anticonvulsant drug binding sites related to GABA-regulated chloride ion channels. In E. Costa, G. DiChiara and G. L. Gessa (Eds.), GABA and Benzodiazepine Receptors Advanc. Biochem. Psychopharmacol., 26 (1981) 93-102.

33 Olsen, R. W. Ticku, M. K., Greenlee, D. and VanNess, P., GABA receptor and ionophore binding sites: interaction with various drugs. In P. Krogsgaard-Larsen, J. Scheel-Krüger and H. Kofod, (Eds.), GABA Neurotransmitters, Academic Press, New York, 1978, pp. 165-178.

34 Olsen, R. W., Ticku, M. K., VanNess, P. C. and Greenlee, D., Effects of drugs on $\gamma$-aminobutyric acid receptors, uptake, release and synthesis in vitro, Brain Research, 139 (1978) 277-294.

35 Placheta, P. and Karobath, M., Regional distribution of $\mathrm{Na}^{+}$-independent GABA and benzodiazepine binding sites in rat CNS, Brain Research, 178 (1979) 580-583.

36 Ransom, B. R., Bullock, P. N. and Nelson, P. G., Mouse spinal cord in cell culture. II. Neuronal chemosensitivity and its relationship to synaptic activity, $J$. Neurophysiol., 40 (1977) $1163-1177$.

37 Ransom, B. R., Neale, E., Henkart, M., Bullock, P. N. and Nelson, P. G., Mouse spinal cord in cell culture. I. Morphology and intrinsic neuronal electrophysiologic properties, J. Neurophysiol., 40 (1977) 1132-1150.

38 Rosenthal, H. E., A graphic method for the determination and presentation of binding parameters in a complex system, Analyt. Biochem., 20 (1967) 525-532.

39 Sawynok, J. and Labella, F. S., GABA and baclofen potentiate the $\mathrm{K}^{+}$-evoked release of methionine-enkephalin from rat striatal slices, Europ. J. Pharmacol, 70 (1981) 103-110.
40 Scatchard, G., The attractions of proteins for small molecules and ions, Ann. N.Y. Acad. Sci., 51 (1949) 660-672.

41 Schechter, P. J. and Tranier, Y., Effect of elevated brain GABA concentrations on the actions of bicuculline and picrotoxin in mice, Psychopharmacology, 54 (1977) 145-148.

42 Shank, R. P., Pong, S. F., Freeman, A. R. and Graham, L. T., Bicuculline and picrotoxin as antagonists of $\gamma$ aminobutyric and neuromuscular inhibition in the lobster, Brain Research, 72 (1974) $71-78$.

43 Sine, S. and Taylor, P., Functional consequences of agonist-mediatd state transitions in the cholinergic receptor, J. biol. Chem., 254 (1979) 3315-3325.

44 Snodgrass, S. R., Use of ${ }^{3} \mathrm{H}$-muscimol for GABA receptor studies, Nature (Lond.), 273 (1978) $392-394$.

45 Snodgrass, S. R., White, W. F., Biales, B. and Dichter, M. Biochemical correlates of GABA function in rat cortical neurons in culture, Brain Research, 190 (1980) 123137

46 Stoof, J. C., Den Breejen, E. J. S. and Mulder, A. H., GABA modulates the release of dopamine and acetylcholine from rat caudate nucleus slices, Europ. J. Pharmacol., 57 (1979) 35-42.

47 Takeuchi, A. and Onodera, K., Effect of bicuculline on the GABA receptor of the crayfish neuromuscular junction, Nature New Biol., 236 (1972) 55-56.

48 Ticku, M. K., Ban, M. and Olsen, R. W., Binding of $\left[{ }^{3} \mathrm{H}\right]$ dihydropicrotoxinin, a $y$-aminobutyric acid synaptic antagonist, to rat brain membranes, Molec. Pharmacol. 14 (1978) 391-402.

49 Ticku, M. K., Huang, A. and Barker, J. L.., CABA receptor binding in cultured mammalian spinal cord neurons, Brain Research, 182 (1980) 201-206.

50 Toffano, G., Guidotti, A. and Costa, E., Purification of an endogenous protein inhibitor of the high affinity binding of $\gamma$-aminobutyric acid to synaptic membranes of rat brain, Proc. nat. Acad. Sci. (U.S.A.), 75 (1978) 4024-4028.

51 Waddington, J. L. and Cross, A. I., Denervation supersensitivity in the striatonigral GABA pathway, Nature (Lond.), 76 (1978) 618-620.

52 Waddington, J. L. and Cross, A. J., Characterisation of denervation supersensitivity in the striatonigral GABA pathway of the kainic acid-lesioned rat and in Huntington's disease, Brain Res. Bull., 5 (1980) 825-828.

53 Weber, M., David-Pfeuty, T. and Changeux, J.-P., Regulation of binding properties of the nicotinic receptor by cholinergic ligands in membrane fragments from Torpedo marmorata, Proc. nat. Acad. Sci. (U.S.A.), 72 (1975) 3443-3447.

54 Williams, M. and Risley, E. A., Characterization of the binding of $3 \mathrm{H}$-muscimol, a potent $\gamma$-aminobutyric acid agonist, to rat brain synaptosomal membranes using a filtration assay, $J$. Neurochem., 32 (1979) 713-718,

55 Wong, D. T. and Horng, J. S., Na-independent binding of GABA to the Triton X-100 treated synaptic membranes from cerebellum of rat brain, Life Sci., 20 (1977) 445-452.

56 Zukin, S. R., Young, A. B. and Snyder, S. H., Gammaaminobutyric acid binding to receptor sites in the rat central nervous system, Proc. nat. Acad. Sci (U.S.A.), 71 (1974) 4802-4807. 